\title{
THE FINANCIAL MANAGEMENT AND REGIONAL DEVELOPMENT
}

\author{
Mihaela Brîndușa Tudose \\ Technical University “Gh. Asachi” of Iaşi \\ brindusatudose@gmail.com
}

\begin{abstract}
The main objective of the study is to examine the role that financial management plays in ensuring regional development. This is because the crisis, economic globalisation, the increasing external growth of companies and the institutionalisation of the autonomy of local communities have fuelled the interest in identifying alternatives to local and thereby regional development. The targeted operational objectives were: to define the preliminary coordinates of regional development; to identify the role of private and public financial management in supporting regional development; and to present the financing framework of the Siret-Prut-Nistru Euroregion. The main financial levers with a direct impact on regional economic development there are: tax incentives; using EU financing programmes; leverage based on ownership of buildings and land; business incubators, etc. The study suggests that financial management (both public and private) plays an important role in the development of the Euroregion, with wideranging present (in the post-crisis) as well as future implications.
\end{abstract}

\section{Keywords}

financial management; public sector; private sector; regional community; regional development; Siret-Prut-Nistru Euroregion; crisis

\section{JEL Classification}

G32; O10

\section{Introduction}

Regional development is a primarily economic, applied to a territory, which focuses on the regional community. The policy achieves its objectives by identifying and leveraging resources at the regional level, the ultimate goal being to create and maintain a stable and profitable business climate. In economic and social terms, the results of regional development are assessed by the volume of investments, the increase in productivity and competitiveness, demographic evolution, living standards, the extent to which disparities within the region are reduced, etc. Financially, the results of regional development are reflected in the size of public and private resources generated at the regional level.

The methodology employed for the purposes of this article relied on hypothesis and deduction. The main objective of the study is to examine the role that financial management plays in ensuring regional development. To achieve this goal, the paper is structured as follows: the first section presents the preliminary coordinates of regional development; section two presents the role of local public financial management in supporting regional development; the third section presents the role of private financial management in the context of regional development concerns; in the fourth section is identified the financing framework of Siret-Prut-Nistru Euroregion; the last section summarizes the conclusions and shows future directions of research. 


\section{Preliminary coordinates of regional development}

Regional development policy targets at a particular area (i.e. territory); this territory along with its population (individuals, groups, professional/employers/trade union associations, educational bodies, NGOs) and their particular activities, traditions and interests make up the regional community. In terms of the direct effects it produces, regional development policy serves primarily the interest of the respective community/area, however - at a subjacent level - it also supports national interest (owing to its favourable impact on the economy or society as a whole). The effective delivery of regional development policies involves carrying out activities designed and implemented by local (public and private) stakeholders, through a set of specific programs and projects. The ultimate goal of these policies is to ensure the growth in the welfare of members of communities and of businesses.

Growth conditions for new businesses and their role in regional development will vary according to the characteristics of the regional environment, and thus different regions may well have quite different types of growth regimes (Fritsch, 2011).

Recent literature concerning regional development has placed significant emphasis on local institutional structures and their capacity to hold down the global. Conversely, work on inter-firm networks - such as the global commodity chain approach - has highlighted the significance of the organizational structures of global firms' production systems and their relation to industrial upgrading (Coe et all, 2004)

Recent studies (Vittoria and Lavadera, 2014) have revealed that a new definition of regional milieu is emerging from the recent innovation policy framework inspired by the notion of a 'knowledge economy'. It is grounded in a theoretical context where the emphasis is on the interactive character of innovation, involving the sharing and exchange of different forms of knowledge among the actors.

The stakeholders operating in the regional arena may act both as contributors and / or beneficiaries of policies executed at this level. Regional economic development is the result of collective actions of: the local public sector, the private sector (local and regional) and local and regional community, respectively. The public sector, represented in particular by local government (but not excluding the involvement of central government), performs the following roles: analyse the local and regional economy; coordinate local and regional economic development; manage local and regional development projects; provide public services; create a favourable climate for various activities, etc. The private sector is composed of businesses that fulfil the following roles: create jobs; contribute to the creation of funds; participate in local and regional strategic planning; jointly participate in providing local public services, etc. The regional community is a joint participant in regional economic development, either directly (by conducting specific activities, including direct investment) or indirectly (through debates, exchanges, guidelines, etc.).

The three main stakeholders in regional development (the public sector, the private and sector and the community) operate on two levels: a) the national economic context (shaped by the government's economic policy); b) the international context (determined by a series of policies formulated by various states at international level, as an effect of globalisation).

The strategy for the development of a territory involves monitoring a system of zonal indicators (Popeangă, 2002). In turn, such indicators are grounded on criteria considered as benchmarks for the overall evolution of the area; these criteria should factor in the existence of comparable data, the possibility to group indicators within representative categories, the relevance for the dynamic analysis of evolution, offsetting any recording errors, etc.

The indicators of a region's evolution can be structured as follows: 
a) indicators which describe demographic developments (total population; population density; socio-professional groups; age groups; demographic dependency indices; infant mortality rate);

b) indicators that define the extent of economic activity and business (industrial and agricultural output per capita; turnover per capita; number of employees per one hundred inhabitants; number of companies per one hundred inhabitants; number of individuals engaged in free enterprise per one hundred inhabitants; taxes collected from one hundred inhabitants; foreign capital invested in the area);

c) indicators that reflect infrastructure and public services (number of housing units per one hundred inhabitants; living space per person; number of households per one hundred inhabitants; available drinking water resources per capita; sewage and wastewater network; landscaped areas; total communication routes, including: railways, roads, county roads, village roads; volume of food and non-food retail sales; the number of letters and parcels delivered per one hundred inhabitants);

d) indicators of household assets and resources in a particular area (number of private automobiles per one hundred inhabitants; telephones per hundred inhabitants; TV subscriptions per one hundred inhabitants; the number of postal offices in the area; the number of bank branches area);

e) socio-cultural, educational and health indicators (active population per one hundred inhabitants; employment rate per one hundred people; unemployment per one hundred inhabitants; social protection expenditure; the number of libraries in an administrative area);

f) ecological and environmental protection indicators (number of sources of pollution in the area; forest land affected by pollution; environmental protection spending).

Both globalisation and regional integration leads to increased competition among local communities for financial assistance, attracting businesses and investment aimed at the local and regional economy. Beyond the advantages provided (by providing economic opportunities on new markets for businesses), globalisation also creates threats to local businesses, because - most often - they cannot compete with major international competitors who sell their products on the local / regional market.

\section{The role of local public financial management in supporting regional development}

Supporting regional development is a major responsibility of public authorities (local ones in particular). Community progress is dependent upon the capacity of local leaders to link public decisions with new economic and social conditions. For these purposes, local government must have thorough knowledge of the community's human, intellectual and financial resources.

The role of financial management is to create a favourable framework for action, where natural connections are established between financial objectives and the means and instruments used to measure its performance (Onofrei et. al, 2011). For that reason, modern public financial management is oriented in such a manner so as to ensure the following: achieving effectiveness; recognising individual responsibilities in carrying out public duties, decentralisation of responsibilities; the introduction and development of strategic management; the outsourcing of certain services to the private sector; the introduction of modern management techniques.

The manner in which local public financial management pursues its above-mentioned role depends on how its functions are fulfilled (Székely, 2009):

a) financial forecasting - a function meant to transpose any strategic objective and tactical decision into income and expenditure, receipts and payments;

b) financial organisation - a function that aims to coordinate the activities required to achieve financial objectives; 
c) financial coordination - a function intended to harmonise decisions and actions of the staff of an entity and its sub-systems as part of its strategies, tactical procedures and organisational system; coordination and thereby communication, especially in the financial area, must be controllable and controlled;

d) financial training - a function that seeks to predetermine an entity's staff to achieve its objectives, by observing the established efficiency conditions;

e) financial control and assessment - a function designed to quantify the performance of the other attributes of management action (forecasting, organisation, coordination and training), conducted at the closing of management cycle, thus laying the foundation and launching the next cycle.

For the purposes of carrying out local public financial management, local authorities have access to a variety of financial instruments to promote regional economic development. Considering the current economic situation and limited available resources, the main financial levers with a direct impact on regional economic development may include (Ichim, 2009): tax incentives; using EU financing programmes; leverage based on ownership of buildings and land; business incubators etc.

Tax incentives are tools that can favour/boost/motivate local stakeholders in their capacity as taxpayers (by reducing the tax burden). Although in the short term, they may appear to benefit only local taxpayers, in the long term, local authorities can also reap beneficial effects, gaining from an increase in resources from activities bolstered by such tools. The provision of tax incentives is recommended when the overall conditions in a particular local/regional jurisdiction are unfavourable to businesses compared to those in other areas where they might relocate (because they could minimise the risk of the flight of taxpayers to a more favourable tax area). Unfortunately, tax incentives can be applied only if local authorities can afford to abandon, over the short term, part of the current guaranteed receipts in exchange for potentially higher future revenue.

Specifically, tax incentives may focus on: a) the establishment of new businesses and/or support for existing businesses; b) creating new jobs and/or protecting existing ones; c) encouraging companies to start new businesses or undertake investment programs aimed at increasing overall productivity and long-term viability.

The decision to offer tax incentives must be judged based on the following two criteria: the expected impact of the decline in current revenue on local public services and the predictability of benefits to be secured by granting tax incentives.

Given that, as mentioned above, the opportunities to support local economic development through tax incentives are relatively limited, it is necessary to correlate the action of such tools with other specific mechanisms (such as those derived from expenditure policy oriented towards supporting local/regional development).

Using EU financing programmes represent another alternative in supporting regional development. For example, Regional Operational Programme 2014-2020 has the overall objective of economic competitiveness and improve living conditions of local and regional communities. The involvement of local authorities at this level is intended not only to aid in fund-raising (by means of consulting, facilitating contacts and providing information), but also to establish partnerships that ought to provide effective support for regional development.

Leverage based on buildings and land ownership. Depending on their category, local authorities may use assets in the private domain of state (specifically, buildings and/or land) to facilitate raising funds on their own behalf or on that of local actors (by providing legal guarantees). Such leverage can be exercised in the opposite direction too. For instance, when a company needs a specific property guarantee that the local authority is able to provide from its own portfolio, the local authority may provide such 
property (or more favourable lease terms) in exchange for a share in the company's capital.

Business incubators, providing managed business space for new businesses, can also support regional development; in particular, appropriate land may be granted (at reasonable lease rates) for the construction of production facilities allowing small enterprises to develop and expand. In addition, authorities can provide: a) shared services, such as safety, maintenance and repair, cleaning, administrative services; b) common facilities (conference rooms, reception desks, business services, warehousing, payroll and billing services); and c) equipment that can shared (such as computers, faxes and copy machines etc.).

In conclusion, we consider that local public financial management plays a major role in supporting the regional development; the separate or joint application of the abovementioned financial levers will allow local authorities to stimulate local and regional economic activity.

\section{The role of private financial management in the context of regional development concerns}

In this section, we will address the role played by firms (through their financing policies) in supporting regional development. Specifically, we will present the manner in which firms have adapted their financial management to current changes, due to the transition from the old challenge (role of leverage in maximising firm value) to the new challenge: financial fragility and vulnerability to crises. This is because, against the backdrop of major imbalances, increased debt financing increases risk, causing companies to become more fragile financially; on the other hand, internal financing, being more stable and sustainable, involves lower levels of risk and mitigates financial vulnerability to crises. The vulnerability of the economic environment extends to the other components of global society; the aggregate effect can translate into a slowdown/stagnation/decline in the pace of regional development.

We would like to emphasise the fact that not only companies, but also the current economic and financial system need more prudent financing that should support a more stable and sustainable growth rate, and in this context, the earlier focus on profit maximisation must be redefined in favour of securing financial sustainability. Only under such conditions can regional development be sustainable.

\section{The financing framework of Siret-Prut-Nistru Euroregion}

The implementation of such actions is illustrated by such concrete examples as the establishment Siret-Prut-Nistru Euroregion itself, and the projects implemented by district councils of partners in the Republic of Moldova in cooperation with Vaslui and Iasi County Councils (projects such as: "The demonstrative use of alternative energy resources in Moldova by means of the experimental cultivation of ALTER ENERGY crops; "Eco-rural tourism in Codrii Lăpuşnei"; "Enhancing businesswomen's entrepreneurship - the creation of a cross-border network; "Prevention of human trafficking”; "The association of border regions in Moldova and the creation of a network of public and private actors involved in socio-economic regional and crossborder initiatives”, "The economic and social development strategy of the Siret-PrutNistru Euroregion”, "The rehabilitation and upgrading of the transport infrastructure in the Iasi - Ungheni border region along road section DJ 249 A”).

The main source of financing of the Euroregion is represented by the financing programmes offered by international bodies (in particular European funds). Due to the major share of non-reimbursable funding (granted for specific purposes), most 
associations in the Siret-Prut-Nistru Euroregion are active in the social and education sphere or carry out activities that contribute to the economic development of the territories in which they operate.

Another source of financing for the Euroregion (admittedly, with a more modest share) is local government budgets. The financial and budgetary reality of present-day Romania is challenging, being marked not only by the extended economic and financial crisis but also by other issues related to the design and implementation of public management. This explains the difficulties faced in co-financing projects implemented using EU financing programmes. The current legal framework (the Tax Code) expressly provides the possibility for local councils to approve certain tax exemptions for building and land taxes, payable by legal entities, for the purposes of regional development. Taking advantage of this legal provision, the local authorities in the two partner counties in the Siret-Prut-Nistru Euroregion have adapted their tax policy in such a way as to support the objectives undertaken upon signing the Euroregion partnership document.

A third source of financing is the funds of businesses that operate in the Euroregion area. The unfavourable national context caused by the crisis and the systemic credit crunch have vastly limited the private sector's financing alternatives and therefore the possibility to co-finance regional development projects.

Even if private financial management does not have a direct impact on the development capacity of the Siret-Prut-Nistru Euroregion, certainly it can influence indirectly the prospects of achieving the objectives undertaken.

Consequently, in the current financial and economic context, the main objective of financial management in the Euroregion should be to secure funding from nonreimbursable grants to offset the loss of public and private resources (as a result of contracting economic activities at national level).

\section{Conclusions}

Regardless of the level to which it relates (whether national, regional, local or private), the primary responsibility of financial management is to identify and secure resources in order to facilitate the achievement of objectives undertaken (by the state, region, local community, business or individual).

Regional development is a policy which aims to ensure the establishment /development/modernisation of enterprises, to create and upgrade infrastructure, to facilitate employment, to implement social policies, to modernise cities and villages, etc. The objectives of the policy are achieved by identifying and leveraging resources at regional level, the ultimate goal being to create and maintain a stable and profitable business climate.

The examination of the particular aspects of financing regional development, in general, and the Siret-Prut-Nistru Euroregion, in particular, was prompted by the present economic and financial context, which has left its mark on regional development opportunities. The research conducted has enabled us to identify the following particular aspects of regional funding:

a) it involves actions undertaken in a particular territorial framework (region), yet whose effects become visible at the national level;

b) it differs in terms of volume, structure and purpose depending on the needs of each individual region (precisely in order to reduce economic and social development disparities);

c) it is based on three main categories of resources: local public resources, local private resources and financing programmes/projects;

d) as it involves the use of local public resources, regional financing necessitates local autonomy and financial decentralisation; 
e) in the case of accessing regional financing schemes, financing is provided after the completing specific phases of project implementation (in the form of repayment of expenses after investments have been made);

f) it involves co-financing on the part of the beneficiary (especially for programmes and projects providing non-reimbursable financing).

The final conclusion is that financial management (both public and private) plays an important role in regional development, with wide-ranging present (against the backdrop of the global crisis) and future implications.

Future directions of research. The study constitutes a starting point for further research. Specifically, we consider the quantification of the financial management impact on regional development.

\section{References}

Coe, M., Hess, M., Yeung H.W., Henderson, J. (2004), Globalizing' regional development: a global production networks perspective, Transactions of the Institute of British Geographers, 29(4), 468-484.

Fritsch, M. (2011), New Business Formation and Regional Development - A Survey and Assessment of the Evidence, Discussion Papers 1127, Berlin.

Ichim, C. (2009), Procesul bugetar local şi dezvoltarea economică locală, Economie teoretică şi aplicată, Supliment, 1, 134-141.

Onofrei, M., Tudose M. B., Oprea, F. (2011), Analiza calităţii deciziilor financiare ale colectivităţilor locale în contextul constrângerilor bugetare [Analysis of the quality of the financial decisions of local authorities in the context of budgetary constraints], paper presented at the international conference „Economie şi cunoaştere" (Economy and Knowledge) organised by the Romanian Academy in partnership with Al. I. Cuza University of Iaşi, 20-22 October 2011.

Popeangă, G. (2002), Managementul finanţelor publice locale, Bucharest, Editura Expert.

Székely, S. Z. (2009), Management financiar. Contabilitatea instituţiilor bugetare, course support material, Cluj-Napoca, Babeş-Bolyai University.

Vittoria, M. P., Lavadera, G. L. (2014), Knowledge networks and dynamic capabilities as the new regional policy milieu. A social network analysis of the Campania biotechnology community in southern Italy, Entrepreneurship \& Regional Development: An International Journal, 26(7), 594-618. 